\title{
Carbapenem resistance in Canada
}

\author{
Baldwin Toye MD, Sigmund Krajden MD, Milan Fuksa DSc, Donald E. Low MD, Dylan R. Pillai MD PhD
}

$\mathrm{F}$ or more than 2 decades, carbapenems have been considered the pharmacotherapy of last resort for managing multidrug-resistant infections caused by Enterobacteriaceae bacteria (e.g., Escherichia coli and Salmonella). Over the past decade, however, resistance to carbapenems has emerged and appears to be increasing among these pathogens, particularly Klebsiella pneumoniae. The mechanism of resistance is the bacterium's production of $\beta$-lactamase enzymes, which hydrolyze carbapenem antibiotics and render them inactive. ${ }^{1,2}$ The $K$. pneumoniae carbapenemase (KPC) $\beta$-lactamases have a very broad spectrum of resistance and can inactivate virtually all other $\beta$-lactam antibiotics. In this article, we describe the epidemiologic features of infections with KPC-producing organisms, including their emergence in Canada, and the challenges in diagnosing and managing these infections.

\section{Epidemiology}

First described in $K$. pneumoniae, KPC enzymes have now been found in other Enterobacteriaceae bacteria. ${ }^{1-3}$ The wide

Table 1: Key features of organisms that produce Klebsiella pneumoniae carbapenemase (KPC) enzymes

\begin{tabular}{|c|c|}
\hline Feature & Details \\
\hline $\begin{array}{l}\text { Geographic } \\
\text { spread }\end{array}$ & $\begin{array}{l}\text { Canada, China, France, Greece, Israel, South } \\
\text { America, United Kingdom, United States }\end{array}$ \\
\hline $\begin{array}{l}\text { Affected } \\
\text { antibiotics }\end{array}$ & $\begin{array}{l}\text { Direct: } \beta \text {-lactam antibiotics } \\
\text { Indirect: fluoroquinolones, aminoglycosides, } \\
\text { trimethoprim-sulfamethoxazole }\end{array}$ \\
\hline $\begin{array}{l}\text { Bacterial } \\
\text { species }\end{array}$ & $\begin{array}{l}\text { K. pneumoniae, Escherichia coli, and } \\
\text { Enterobacter, Citrobacter and Salmonella species }\end{array}$ \\
\hline Risk factors & $\begin{array}{l}\text { Admission to intensive care unit; mechanical } \\
\text { ventilation; previous use of antibiotics; poor } \\
\text { general health; recent receipt of transplanted } \\
\text { organ or stem cells; travel to an endemic area }\end{array}$ \\
\hline $\begin{array}{l}\text { Mechanism } \\
\text { of resistance }\end{array}$ & $\begin{array}{l}\text { Plasmid-encoded gene }\left(b / a_{\mathrm{KPC}}\right) \text { enables } \\
\text { hydrolysis of } \beta \text {-lactam antibiotics }\end{array}$ \\
\hline $\begin{array}{l}\text { Methods of } \\
\text { laboratory } \\
\text { detection }\end{array}$ & $\begin{array}{l}\text { Ertapenem to screen isolates; modified Hodge } \\
\text { test to detect KPC activity; polymerase chain } \\
\text { reaction assay to confirm presence of } b / a_{\mathrm{KPC}}\end{array}$ \\
\hline $\begin{array}{l}\text { Infection } \\
\text { control }\end{array}$ & $\begin{array}{l}\text { Isolation of infected patients; use of contact- } \\
\text { related precautions; cleansing of environment }\end{array}$ \\
\hline $\begin{array}{l}\text { Alternative } \\
\text { antibiotics }\end{array}$ & $\begin{array}{l}\text { Tigecycline or colistin; choice of antibiotic } \\
\text { should be guided by susceptibility testing }\end{array}$ \\
\hline
\end{tabular}

dissemination and transfer between bacterial species has occurred because KPC genes are carried on plasmids. Key features of organisms that produce KPC enzymes are summarized in Table 1.

Large nosocomial and city-wide outbreaks of infections with KPC-producing organisms have been reported predominantly in the United States, especially in northeastern states such as New York. ${ }^{4,5}$ Other outbreaks have occurred in Israel, the United Kingdom, Greece, France, China and South America. ${ }^{2,6-9}$ As with other gram-negative pathogens, KPC-producing organisms have been readily transmitted nosocomially through clonal spread and are now endemic in some hospitals. Outbreaks have also been reported in long-term care facilities. ${ }^{3}$

Risk factors include admission to an intensive care unit, mechanical ventilation, previous use of antibiotics, poor general health and recent receipt of transplanted organs or stem cells. ${ }^{7,10}$ Infection with KPC-producing organisms is associated with a high mortality (up to $40 \%-50 \%$ ) and constitutes an independent risk factor of death. $5,7,10$

The prevalence of KPC-producing pathogens in Canada is currently unknown because laboratories may not be using the most sensitive methods for detection.

\section{Diagnosis}

The routine methods of detection and the automated systems commonly used by clinical laboratories may fail to consistently detect KPC-producing organisms. The pathogens may test as "susceptible" to carbapenems such as meropenem and imipenem using the usual interpretive criteria. In 2008, 10 isolates of $K$. pneumoniae were referred to the Ontario Public Health Laboratories for further testing. ${ }^{11,12}$ The initial results of susceptibility testing of 1 of the 10 isolates using an automated method suggested that the organism was susceptible to meropenem. However, the initial results of testing using routine clinical laboratory methods showed general resistance to all lactams, with complete or intermediate resistance to meropenem, which raised the possibility of KPC production.

From the Department of Microbiology, Ottawa Hospital and University of Ottawa (Toye), Ottawa, Ont.; the Ontario Agency for Health Protection and Promotion (Toye, Low, Pillai), Toronto, Ont.; the Department of Microbiology, St. Joseph's Health Centre (Krajden, Fuksa), Toronto, Ont.; the Department of Laboratory Medicine and Pathobiology, University of Toronto (Krajden, Low, Pillai), Toronto, Ont.; and the Division of Infectious Diseases, University Health Network (Low, Pillai), Toronto, Ont. 
This discrepancy could mislead a clinician into thinking that the carbapenem class of antibiotics is useful. When the 10 isolates were subsequently tested using phenotypic and molecular methods, all were confirmed to be producers of KPC.

Canadian laboratories should screen for KPC production, as recently recommended by the 2009 Clinical Laboratory Standards Institute. ${ }^{13}$ KPC production should be suspected if in vitro testing shows resistance or reduced susceptibility to a carbapenem. Isolates of $K$. pneumoniae that are resistant to any of the extended-spectrum cephalosporins but that test "susceptible" to the carbapenems should also be evaluated for possible production of KPC. Screening with ertapenem is preferred, since this agent is more susceptible than other carbapenems to KPC hydrolysis. ${ }^{13,14}$ Confirmation of carbapenemase activity can be performed phenotypically using the modified Hodge test. ${ }^{15}$ Public health laboratories and other reference laboratories that can perform molecular testing should specifically confirm the presence of the $b l a_{\mathrm{KPC}}$ gene using techniques such as the polymerase chain reaction..$^{14,15}$

\section{Management}

Treatment of infections with KPC-producing organisms is problematic because of limited therapeutic options. ${ }^{2,16}$ Fluoroquinolones, aminoglycosides or cotrimoxazole may be used if the organism is susceptible. More commonly, the pathogen will be resistant to these antibiotics, as shown by recent trends of resistance in Enterobacteriaceae. ${ }^{17}$ Anecdotal reports suggest that tigecycline (a glycylcycline) or colistin (a polymyxin) may be effective. ${ }^{18,19}$ However, tigecycline may not be suitable for septicemia, and colistin is associated with nephrotoxic and neurotoxic effects.

Despite the absence of definitive evidence, it would seem prudent to isolate infected patients and take contact-related precautions because of the potential for nosocomial transmission. ${ }^{20}$ Resistance genes encoded by plasmids have a theoretical risk of rapid transmission from one species to the next, which implies that rigorous measures to limit the spread of infection will be crucial. The emergence of KPC-producing organisms in Canada reinforces the need for antimicrobial stewardship as a strategy to control the spread of these extremely drug-resistant organisms. ${ }^{21}$

\section{This article has been peer reviewed.}

Competing interests: None declared.

Contributors: All of the authors contributed to the conception of the article, were involved in the drafting and revision of the manuscript and approved the final version submitted for publication.

\section{REFERENCES}

1. Walther-Rasmussen J, Høiby N. Class A carbapenemases. J Antimicrob Chemother 2007;60:470-82.

2. Queenan AM, Bush K. Carbapenemases: the versatile $\beta$-lactamases. Clin Microbiol Rev 2007;20:440-58.

3. Urban C, Bradford PA, Tuckman M, et al. Carbapenem-resistant Escherichia coli harboring Klebsiella pneumoniae carbapenemase $\beta$-lactamases associated with long-term care facilities. Clin Infect Dis 2008;46:e127-30.

4. Bradford PA, Bratu S, Urban C, et al. Emergence of carbapenem-resistant Klebsiella species possessing the class A carbapenem-hydrolyzing KPC-2 and inhibitorresistant TEM-30ß-lactamases in New York City. Clin Infect Dis 2004;39:55-60.

5. Bratu S, Landman D, Haag R, et al. Rapid spread of carbapenem-resistant Klebsiella pneumoniae in New York City. Arch Intern Med 2005;165:1430-5.

6. Woodford N, Zhang J, Warner M, et al. Arrival of Klebsiella pneumoniae producing KPC carbapenemase in the United Kingdom. J Antimicrob Chemother 2008; 62:1261-4.

7. Schwaber MJ, Klarfeld-Lidji S, Navon-Venezia S, et al. Predictors of carbapenemresistant Klebsiella pneumoniae acquisition among hospitalized adults and effect of acquisition on mortality. Antimicrob Agents Chemother 2008;52:1028-33.

8. Villegas MV, Lolans K, Correa A, et al.; Colombian Nosocomial Resistance Study Group. First detection of the plasmid-mediated class A carbapenemase KPC-2 in clinical isolates of Klebsiella pneumoniae from South America. Antimicrob Agents Chemother 2006;50:2880-2.

9. Tsakris A, Kristo I, Poulou A, et al. First occurrence of KPC-2-possessing Klebsiella pneumoniae in a Greek hospital and recommendation for detection with boronic acid disc tests. J Antimicrob Chemother 2008;62:1257-60.

10. Patel G, Huprikar S, Factor SH, et al. Outcomes of carbapenem-resistant Klebsiella pneumoniae infection and the impact of antimicrobial and adjunctive therapies. Infect Control Hosp Epidemiol 2008;29:1099-106.

11. Pillai DR, Melano R, Rawte P, et al. Klebsiella pneumoniae carbapenemase, Canada [letter]. Emerg Infect Dis 2009;15(5). Available: www.cdc.gov/EID /content/15/5/827.htm (accessed 2009 Apr. 28).

12. Goldfarb D, Harvey SB, Jessamine K, et al. Detection of plasmid mediated KPCproducing Klebsiella pneumoniae in Ottawa, Canada: evidence of intra-hospital transmission. J Clin Microbiol 2009 Apr. 8 [Epub ahead of print].

13. Clinical Laboratory Standards Institute. Performance standards for antimicrobial susceptibility testing; nineteenth informational supplement. Wayne (PA): The Institute; 2009. Available: www.clsi.org/source/orders/free/m100-s19.pdf (accessed 2009 Apr. 28)

14. Cole JM, Schuetz AN, Hill CE, et al. Development and evaluation of a real-time PCR assay for the detection of Klebsiella pneumoniae carbapenemase genes. $J$ Clin Microbiol 2009;47:322-6. Epub 2008 Nov. 26.

15. Anderson KF, Lonsway DR, Rasheed JK, et al. Evaluation of methods to identify the Klebsiella pneumoniae carbapenemase in Enterobacteriaceae. J Clin Microbiol 2007;45:2723-5.

16. McGettigan SE, Andreaecchio K, Edelstein PH. Specificity of ertapenem susceptibility screening for the detection of Klebsiella pneumoniae carbapenemases (KPC). J Clin Microbiol 2009;47:785-6. Epub 2009 Jan. 14

17. Pitout JD. Multiresistant Enterobacteriaceae: new threat of an old problem. Expert Rev Anti Infect Ther 2008;6:657-69.

18. Falagas ME, Kasiakou SK. Colistin: the revival of polymyxins for the management of multidrug-resistant gram-negative bacterial infections. Clin Infect Dis 2005;40:1333-41.

19. Bratu S, Tolaney P, Karumudi U, et al. Carbapenemase-producing Klebsiella pneumoniae in Brooklyn, NY: molecular epidemiology and in vitro activity of polymyxin B and other agents. J Antimicrob Chemother 2005;56:128-32.

20. Srinivasan A., Patel J.B. Klebsiella pneumoniae carbapenemase-producing organisms: An ounce of prevention really is worth a pound of cure. Infect Control Hosp Epidemiol 2008;29:1107-9.

21. Dellit TH, Owens RC, McGowan JE Jr., et al. Infectious Diseases Society of America and the Society for Healthcare Epidemiology of America Guidelines for Developing an Institutional Program to Enhance Antimicrobial Stewardship. Clin Infect Dis 2007;44:159-77.

Correspondence to: Dr. Dylan R. Pillai, Ontario Agency for Health Protection and Promotion, 81 Resources Rd., Toronto ON M9P 3T1; fax 416 235-6281; dylan.pillai@oahpp.ca 